\title{
Prevalence and characteristics of Aggressive Periodontitis
}

\author{
Diatri Nariratih*), Yanti Rusyanti*, Agus Susanto* \\ *Department of Periodontics Faculty of Dentistry Universitas Padjadjaran, Bandung
}

\section{ABSTRACT}

Aggressive Periodontitis is one of periodontal disease that generally affects individuals less than 30 years old, with a rapid attachment loss and alveolar bone destruction. Special features of the disease are affected incisors and first molars with symmetrical bilateral destruction. The purpose of this study was to determine the prevalence and characteristics of Aggressive Periodontitis at Student Clinics, Faculty of Dentistry Padjadjaran University on May to July 2010. Based on accidentally sampling, 415 new patients at Dental and Oral Hospital, Faculty of Dentistry Padjadjaran University and Dental and Oral Polyclinic at RSUP dr. Hasan Sadikin Bandung were participated in this study. Each subject filled out the questionnaire and did clinical examination. Patients with attachment loss $\geq 4 \mathrm{~mm}$ were reffered for radiographic and microbiologic examination to support the diagnosis. The results showed that there were 13 patients who has the diagnostic criteria of Aggressive Periodontitis. Nine patients were diagnosed as Localized Aggressive Periodontitis, and 4 patients as Generalized Aggresive Periodontitis. It is concluded that the prevalence of Aggressive Periodontitis was 3.13\%, and indicated low prevalence. Characteristics of Localized Aggressive Periodontitis patients were female in 20-29 age range, whereas characteristics of Generalized Aggressive Periodontitis patients were male in 30-39 age range.

Key words: Aggressive periodontitis, prevalence, characteristics

\section{ABSTRAK}

Periodontitis Agresif merupakan salah satu penyakit periodontal yang umumnya mengenai individu dibawah usia 30 tahun dengan hilangnya perlekatan klinis dan destruksi tulang alveolar yang cepat. Penyakit ini memiliki karakteristik khusus yaitu mengenai gigi insisif dan molar pertama dengan gambaran destruksi bilateral simetris. Tujuan penelitian ini adalah untuk mengetahui prevalensi dan karakteristik periodontitis agresif di Klinik Kerja Mahasiswa Fakultas Kedokteran Gigi Universitas Padjadjaran periode Mei-Juli 2010. Teknik yang digunakan adalah accidentally sampling dengan jumlah sampel 415 pasien baru di Rumah Sakit Gigi dan Mulut Fakultas Kedokteran Gigi Universitas Padjadjaran serta Poliklinik Gigi dan Mulut RSUP dr. Hasan Sadikin Bandung. Pengisian kuesioner dan pemeriksaan klinis dilakukan pada setiap subjek. Pemeriksaan radiografis dan mikrobiologis dilakukan pada pasien yang mengalami kehilangan perlekatan klinis $\geq 4 \mathrm{~mm}$ untuk menunjang diagnosis. Hasil penelitian menunjukkan bahwa terdapat 13 orang dengan diagnosis Periodontitis Agresif. Terdiri dari 9 orang penderita Periodontis Agresif Lokalisata dan 4 orang penderita Periodontitis Agresif Generalisata. Simpulan dari penelitian ini adalah prevalensi Periodontitis Agresif rendah, yaitu sebesar 3,13\%. Karakteristik penderita Periodontitis

*) Correspondence author: Diatri Nariratih, Department of Periodontic Faculty of Dentistry Universitas Padjadjaran
Jl. Sekeloa Selatan No. 1 Bandung, West Java-Indonesia, Tel./Fax: $+6222-2504985 / 2532805$ 
Agresif Lokalisata adalah perempuan dengan rentang usia 20-29 tahun, sedangkan penderita Periodontitis Agresif Generalisata adalah laki-laki dengan rentang usia 30-39 tahun.

Kata kunci: periodontitis agresif, prevalensi, karakteristik

\section{INTRODUCTION}

Periodontal disease is one disease with a prevalence of oral cavity and the intensity is still high. An epidemiological study showed that poor oral hygiene or plaque accumulation associated with a high prevalence and severity of periodontal disease. ${ }^{1}$ Prevalence and intensity of periodontal disorders also have a close relationship with the state of geography, social, economic, educational, systemic health, state of the oral cavity, and oral habit. $^{2}$

Periodontitis is one of the periodontal disease that often occurs. According to time of onset and progression of disease, periodontitis is categorized into chronic periodontitis and aggressive periodontitis. Chronic periodontitis can be started at any age with a slow disease progression and clinically visible in mid-age 30 years or more. This disease continues in patients along with increasing age due to the length of the accumulation of plaque on periodontal tissue. It triggers the inflammatory process, resulting in loss of clinical attachment and alveolar bone destruction. Aggressive Periodontitis is common in young age, starting from the age of puberty until the age under 30 years old. At older ages, individuals who suffer from aggressive periodontitis have started to lose teeth due to tooth mobility. Aggressive periodontitis can occur locally or generally. Various factors that influence aggressive periodontitis are subgingival composition of specific microflora, patients with immune system deficiency, genetic, and environmental. Aggressive periodontitis may demonstrate minimal inflammation with loss of clinical attachment and alveolar bone destruction rapid. This can lead to premature tooth loss that impaired function of the oral cavity. ${ }^{3-6}$

Aggressive periodontitis generally occurs in younger patients with a low incidence and prevalence of chronic periodontitis compared. ${ }^{5}$ The existence of specific risk factors such as bacteria, immune deficiencies, genetic, and environmental that cause aggressive periodontitis from some previous studies still vary greatly depending on the population or geographic location. It also may be caused by differences in study methods and different definitions of aggressive periodontitis. ${ }^{3,7}$ Aggressive periodontitis distribution based on gender was still unclear. Some previous research indicates that no significant differences in distribution between men and women. ${ }^{3}$

Epidemiological data remains unclear aggressive periodontitis in Indonesia. However, research on the prevalence of this disease has ever conducted in Periodontic Department Faculty of Dentistry Airlangga University, Surabaya.8 In Bandung itself, there are no epidemiological data on aggressive periodontitis. Prevalence of aggressive periodontitis in Dental Hospital Faculty of Dentistry Padjadjaran University as well as in Hasan Sadikin Hospital Dental Clinic, as the teaching hospitals, is still unknown. As a referral center for dental and oral diseases in Bandung, teaching hospital is a critical place with many cases and diagnosis of diseases. Therefore, from the known prevalence, the existing description the problem can be obtained. ${ }^{9}$ These epidemiological data need to know because they are useful to determine the amount and distribution of disease in a population, to know the cause, to control the disease, to identify risk factors for primary prevention as a reference, as well as an underlying diagnosis, prognosis, and adequate treatment. ${ }^{3}$

Knowing the prevalence and characteristics of aggressive periodontitis patients in Teaching Hospitals Faculty of Dentistry Universitas Padjadjaran, data on the number and characteristics of patients with aggressive periodontitis, causes and risk factors, as well as adequate care are expected to be obtained so that it can prevent loss of teeth at an early age.

\section{METHODS}

This was a descriptive study conducted by survey method. The populations in this study were all patients at the Dental Hospital, Faculty 
of Dentistry, Universitas Padjadjaran as well as General Hospital, dr. Hasan Sadikin Bandung. Sampling technique used was the accidentally sampling. Samples taken from the entire population of new patients in the month of May to July 2010 and meet the population criteria. The exclusion criteria in this study were patients who were not willing to be examined. The study was conducted at the Screening and Radiology Department.

The first step before the examination was charging the informed consent by research subjects. Filling in questionnaires was conducted before the examination to determine age, gender, occupation, last education, and knowledge of the subject of research on periodontal disease, as well as the factors that influence the severity of disease, such as smoking or drug use.

Clinical examination conducted in the form of checks made on attachment loss around teeth. Clinical attachment loss was measured from cementoenamel junction (CEJ) to the basic periodontal pocket. The probe was inserted into the periodontal pocket base with a light pressure and parallel to the long axis of the teeth to be examined. Inspection carried out in six areas on each tooth, the mesiofasial, midfasial, distofasial, mesiolongual, midlingual, and distolingual. Patients with clinical attachment loss of $\geq 4 \mathrm{~mm}$ and suspected to suffer from Aggressive Periodontitis will be conducted radiographic and microbiologic examination to support the diagnosis. Criteria for patients who were suspected to suffer from aggressive periodontitis was patients between the age of puberty until the age of 30 years old and patients with older age with tooth loss due to mobility.

Alveolar bone destruction was seen through radiographic examination using 3D CBCT. Radiographic image of a vertical bone loss or loss on the arch-shaped teeth that experienced attachment loss $\geq 4 \mathrm{~mm}$ showed Aggressive Periodontitis. Microbiological examination of the bacteria Actinobacillus actinomycetescomitans examination from gingival sulcus fluid of patients was done to ensure that there was predominant involvement of pathogenic bacteria in aggressive periodontitis.

Diagnosis was done by analyzing the results of a questionnaire with clinical examination, radiographic, and microbiological. Localized Aggressive Periodontitis occurs in the first molars and in- cisive with clinical attachment loss of $\geq 4 \mathrm{~mm}$ and vertical radiographic image or arch-shaped loss of alveolar bone that extends from the distal surface of the second premolars to the mesial surface of second molars and usually occurs bilaterally. Generalized Aggressive Periodontitis is similar to Localized Aggressive Periodontitis added with at least three teeth other than first molars and incisive, the second molar, canine, or premolar with clinical attachment loss of $\geq 4 \mathrm{~mm}$ and vertical radiographic image or arch-shaped alveolar bone loss around affected teeth. The results of microbiological examination of patients with localized and generalized aggressive periodontitis must indicate the presence of Actinobacillus actinomycetescomitans bacterial colonies.

Prevalence of Aggressive Periodontitis (PAG) was the number or percentage of patients suffering from Aggressive Periodontitis in the Teaching Hospital of Faculty of Dentistry Universitas Padjadjaran within a certain time. Measurements were made as follows:

$\mathrm{PAg}=\frac{\text { The number of patients with aggressive periodontitis }}{\text { The number of patients examined } \times 100 \%}$

Characteristics of aggressive periodontitis were gender and age of aggressive periodontitis patients in teaching hospitals Faculty of Dentistry, Universitas Padjadjaran. The data obtained were described, and then presented in tabular and pie chart.

\section{RESULTS}

Research subjects were 415 people, with the number of subjects in RSGM FKG Unpad many as 311 people and subjects in dr. Hasan Sadikin General Hospital Bandung as many as 104 people. Diagram 1 showed that there were 411 subjects diagnosed with periodontal disease, ranging from gingivitis, periodontitis, epulis, until the enlargement of the gums caused by the consumption of certain drugs with a frequency of most of the subjects with localized chronic gingivitis marginalis. The prevalence of periodontal disease by $99.04 \%$ and there were 13 people with Aggressive Periodontitis from 415 research subjects. Therefore, the obtained prevalence of Aggressive Periodontitis in Teaching Hospitals Faculty of Dentistry, University of Padjadjaran was equal to $3.13 \%$. 


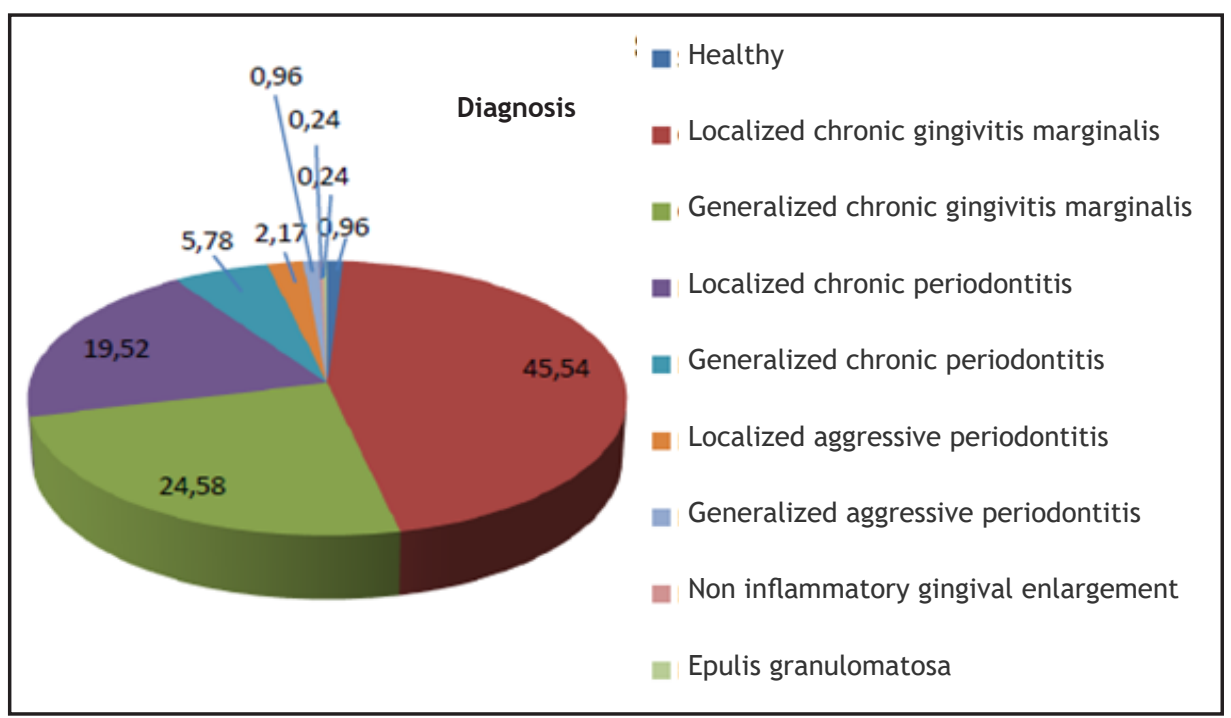

Figure 1. Percentage of disease diagnosis in research subjects.

Characteristics of patients with Aggressive Periodontitis lesions are grouped meunurut distribution, gender, and age. The percentage of aggressive periodontitis based on gender and age can be seen in Table 1. The results in Table 1 shows that the more Aggressive Periodontitis suffered by female subjects. Subjects with Localized Aggressive Periodontitis were all female, while the diagnosis of Generalized Aggressive Periodontitis entirely suffered by male subjects. The diagnosis of Localized Aggressive Periodontitis affects most subjects with age range 20-29 know, while the diagnosis of Generalized Aggressive Periodontitis affects most subjects with age range $30-39$ years old. No subjects with an age range below 30 years old who to suffer from generalized Aggressive Periodontitis.

Knowledge of the research subjects of about periodontal disease obtained from filling

Table 1. Percentage of aggressive periodontitis by gender and age

\begin{tabular}{lcccc} 
& Localized & $\%$ & Generalized & $\%$ \\
\hline $\begin{array}{l}\text { Sex } \\
\text { Male }\end{array}$ & - & - & 4 & 30.77 \\
$\quad$ Female & 9 & 69.23 & - & - \\
Age & & & & \\
$10-19$ & 3 & 23.08 & - & - \\
$20-29$ & 5 & 38.46 & - & - \\
$30-39$ & 1 & 7.69 & 3 & 23.08 \\
$40-49$ & - & - & 1 & 7.69 \\
\hline
\end{tabular}

the questionnaire. This information was needed to support the diagnosis of each subject. Overview about knowledge of 13 patients with Aggressive Periodontitis about periodontal disease was shown in Table 2. It consists of daily frequency of toothbrushing, oral hygiene level, chief complaint, a history of similar complaints on family members, history of previous dental care, as well as the factors that affect the periodontal tissues such as hormonal stage in women and tobacco smoking. In addition, no patients with Aggressive Periodontitis who have systemic disease or taking certain medications.

\section{DISCUSSION}

Disease diagnosis as shown in Diagram 1 was determined by analyzing the results of questionnaires, clinical examination, radiographic examination, and microbiological examination as a supporter. Image of vertical bone resorption or arch-shaped tooth loss in tooth with clinical attachment loss of $\geq 4 \mathrm{~mm}$ showed Aggressive Periodontitis. Microbiological examination was performed to ensure a predominant involvement of pathogenic bacteria in Aggressive Periodontitis. In this study bacterial examined was Actinobacillus actinomycetescomitans, which is the dominant pathogen in Localized Aggressive Periodontitis. ${ }^{3}$ Some problems were found at the time of the study include inaccurate clinical examination with the use of probes as a result of subgingival 
Table 2. Percentage of subjects' knowledge about periodontal disease

\begin{tabular}{|c|c|c|c|c|}
\hline \multicolumn{5}{|l|}{ Toothbrushing frequency } \\
\hline 1 times & 1 & 7.69 & - & - \\
\hline 2 times & 8 & 61.54 & 3 & 23.08 \\
\hline 3 times & - & - & 1 & 7.69 \\
\hline \multicolumn{5}{|l|}{ Oral hygiene level } \\
\hline Bad & 3 & 23.08 & 3 & 23.08 \\
\hline Moderate & 3 & 23.08 & 1 & 7.69 \\
\hline Good & 3 & 23.08 & - & - \\
\hline \multicolumn{5}{|l|}{ Complaint } \\
\hline Tooth mobility & 6 & 20.0 & 4 & 13.33 \\
\hline $\begin{array}{l}\text { Pain during mastication } \\
\text { and/or touched }\end{array}$ & 2 & 6.67 & - & - \\
\hline $\begin{array}{l}\text { Pain in changing } \\
\text { Temperature }\end{array}$ & 2 & 6.67 & - & - \\
\hline $\begin{array}{l}\text { Bleeding during } \\
\text { toothbrushing }\end{array}$ & 7 & 23.33 & 2 & 6.67 \\
\hline $\begin{array}{l}\text { Spontaneous bleeding on } \\
\text { gingiva }\end{array}$ & 1 & 3.33 & - & - \\
\hline Tooth loss & 3 & 10.0 & 3 & 10.0 \\
\hline \multicolumn{5}{|l|}{ Family History } \\
\hline No & 4 & 30.77 & 2 & 15.38 \\
\hline Yes & 5 & 38.46 & 2 & 15.38 \\
\hline \multicolumn{5}{|l|}{ Previous treatment } \\
\hline No & 6 & 46.15 & 2 & 15.38 \\
\hline Yes & 3 & 23.08 & 2 & 15.38 \\
\hline \multicolumn{5}{|l|}{ Hormonal } \\
\hline Menstruation & 3 & 33,33 & - & - \\
\hline \multicolumn{5}{|l|}{ Smoking } \\
\hline No & 9 & 69.23 & 3 & 23.08 \\
\hline Yes & - & - & 1 & 7.69 \\
\hline
\end{tabular}

calculus, radiographic images are less obvious, and obstacles to culture bacteria, such as the location of the remote laboratory so that death may occur in the course of the bacteria, and bacterial plate are easily contaminated, or difficulties in acquiring crevicular fluid.

High prevalence of periodontal disease in the results of this study is in accordance with the 2001 Household Health Survey 10 which suggests that periodontal disease is dental and oral disease complained by $70 \%$ of Indonesia's population. This is due to low awareness and the ability of the communities to prioritize oral health optimally. ${ }^{11}$ Gingivitis itself is an early clinical manifestation of periodontal tissue due to inflammatory processes, thus gingivitis is one most common form of periodontal disease most common. ${ }^{3,12}$

The existence of specific risk factors such as bacteria, immune deficiencies, genetic, and environmental cause aggressive periodontitis prevalence of several previous studies still vary widely, depending on the population or geographic location. ${ }^{7}$ This may also caused by differences in research methods and the definition of aggressive periodontitis. Previous studies in Tehran and Southern Brazil showed a low prevalence. ${ }^{13,14}$ Low prevalence was also found in Afro-American race, Hispanic, and Caucasian. ${ }^{15}$ The results of similar research conducted by Setiawati in Periodontology Department Faculty of Dentistry Universitas Airlangga, Surabaya, shows an increasing prevalence of Aggressive Periodontitis than 9\% in 1991 to $13 \%$ in $2002 .{ }^{8}$ The study was in accordance with the results of this study that showed low prevalence of Aggressive Periodontitis.

Aggressive Periodontitis generally occurs in younger patients with the incidence and prevalence are lower compared with Chronic Periodontitis. ${ }^{5}$ In an Aggressive Periodontitis, increasing number of pathogenic bacteria Actinobacillus actinomycetescomitans and Porphyromonas gigivalis was found. Immune systems are disturbed due to the high virulence of bacterial pathogen-specific immune defects and the presence of abnormalities of neutrophils and monocytes as well as excessive response cause bacterial invasion of periodontal and tissue destruction more rapid and severe. Defective immune and cytokine variations can be lowered so that the disease tends to occur in individuals with blood relations. ${ }^{3}$ To support the diagnosis, all subjects are asked about family history as listed in Table 2. This grouping also can occur when the disease has a genetic component. The existence of genetic factors indicates the family members of patients with risk and susceptibility to aggressive periodontitis. It allows patients had similar complaints and diseases. Patients can inform the disease to family members so that early treatment and adequate to prevent the development and severity of disease on individuals and families. The existence of the same risk factors in a family such as habits and environment, may also explain the involvement of the same bacterial pathogens in a single family. ${ }^{3,5}$ 
Localized Aggressive Periodontitis is usually started at the age of puberty until about age 20 years, whereas generalized aggressive periodontitis usually occurs at ages under 30 years. At older ages, people have started to experience tooth loss due to mobility. ${ }^{3}$ It is in accordance with the results of this study as listed in Table 1 . Table 2 shows the most common complaints of patients with generalized aggressive periodontitis which are tooth mobility and tooth loss due to complaints of mobility.

Based on the results of this study, subjects who suffer from Localized Periodontitis more aggressive compared with Generalized Aggressive Periodontits. Research with this sampling accidentally showed 9 patients Localized Aggressive Periodontitis and 4 patients Generalized Aggressive Periodontitis than 415 research subjects with a prevalence of $3.13 \%$. Similar study by Sadeghi in Tehran, Iran with random cluster sampling 7 patients also showed localized aggressive periodontitis and 1 patient generalized aggressive periodontitis than 5590 pupils aged $15-18$ years with a prevalence of $0.13 \% .^{13}$

Subjects with a diagnosis of Localized Aggressive Periodontitis were all female, while the diagnosis of Generalized Aggressive Periodontitis entirely was suffered by men. Distribution by sex Aggressive Periodontitis remains unclear. Research Hornmand and Frandsen and Barnett et al. ${ }^{16}$ showed a comparison between male patients and female patients are almost the same, that was $1: 2.5$ and $1: 2$. The results were in accordance with that was mentioned by Samaranayake that generalized aggressive periodontitis suffered by women. ${ }^{17}$ Research conducted by Loe and Brown ${ }^{3}$ showed adolescent boys were more easily to suffer from Generalized Periodintitis Aggressive than girls. ${ }^{18}$ Meanwhile, according to Carranza et al. differences in distribution by sex is more visible than in racial group. In blacks, men were 2.9 times more likely to suffer Localized Aggressive Periodontitis than women. On the white race, women were 2.5 times more likely to suffer from Localized Aggressive Periodontitis compared to men. Other studies showed no significant differences in distribution between the prevalence in men and women.

Good oral hygiene is the best prevention in dealing with periodontal disease due to inflamma- tion of the gingival invasion preceded by the presence of specific bacterial pathogens on plaque and calculus. Control of plaque using a toothbrush either manual or electric, and other auxiliary equipment and materials along with regular visits to the dentist at least every 6 months is recommended to prevent the occurrence of periodontal disease. ${ }^{3,19}$ As a result of the high virulence of bacteria, patients suffering from aggressive periodontitis showed severe tissue damage, although there was only little accumulation of plaque bacteria and the patients showed good oral hygiene level. ${ }^{4.7}$ It is not in accordance with the results in Table 2 which shows some of the subjects suffering from aggressive periodontitis have high levels of poor oral hygiene. This suggests a role of local factors of disease severity. The lack of knowledge about oral health is one of those factors.

Table 2 also shows the existence of patients with Generalized Aggressive Periodontitis who had never received previous treatment. Aggressive forms of periodontitis can be transformed from localized to generalized based on age because of the absence of care interventions. However, there are patients who experienced disease progression until tooth loss occurs despite a non-adequate conventional treatment has been done. ${ }^{3,20,21}$

Table 2 also illustrates a systemic disease, smoking, hormonal changes in women, and the consumption of certain drugs. It is important to note when determining diagnosis, prognosis, and selection of appropriate therapy. These risk factors affect the state of periodontal tissues that facilitate and simplify the process of the disease course. ${ }^{12}$ The presence of systemic disease are exclusion criteria in the diagnosis of aggressive periodontitis. ${ }^{7}$ This is in accordance with findings seen in Table 2 shows that there was no Aggressive Periodontitis patients who have systemic disease.

Patients with smoking have risk of 2.8 to 6.7 times more likely to suffer from periodontal diseases compared with patients who did not smoke. In addition, smoking can aggravate the disease and inhibit tissue recovery. ${ }^{12}$ The results showed a man of 13 subjects in the habit of smoking, who suffered from Generalized Aggressive Periodontitis. Patient had a lot of experience tooth loss due to mobility. It shows that the number of affected teeth and tissue destruction in patients with generalized aggressive periodontitis with 
smoking is much more severe compared to patients without smoking habits. ${ }^{3}$ Hormonal factors such as puberty, menstruation, and pregnancy increase the severity of inflamed tissue by local factors, whereas the consumption of certain drugs causes gingival enlargement. ${ }^{3,12}$

Clinical attachment loss and alveolar bone destruction on periodonttiis aggressive fast can lead to tooth loss at an early stage impaired function of the oral cavity. ${ }^{3}$ Data from epidemiological description of the prevalence and characteristics of Aggressive Periodontitis Can be obtained, so that appropriate action can be established to combat the disease.

\section{CONCLUSION}

The conclusion that can be drawn from this study is the prevalence of Aggressive Periodontitis in the Teaching Hospital Faculty of Dentistry Universitas Padjadjaran in the period May to July 2010 was low (3.13\%). Characteristics of patients with Localized Aggressive Periodontitis were female ranging in age 20-19 years, whereas patients with Generalized Aggressive Periodontitis were males with age ranges of 30-39 years.

\section{REFERENCES}

1. Petersen PE, Yamamoto T. Improving the oral health of older people. The approach of the WHO global oral health programme. Comm Dent Oral Epidemiol 2005;33: 81-92.

2. Agtini MD. Epidemiologi dan etiologi penyakit periodontal. Departemen Kesehatan RI. Cermin Dunia Kedokteran 1991;72:42-5.

3. Carranza FA, Newman MG, Takei HH, Klokkevold PR. Clinical periodontology. $10^{\text {th }}$ ed. Missouri: W.B. Saunders Co.; 2006. P. 48-9,56-7,68,100$1,106,110-1,114-5,120-2,128,133,137,160$ $1,170,228-45,252,286,288,312-3,315,326-$ 7,349-50, 355, 362, 364, 366-8, 373, 375, 434, 452,494-9,506-11,551,584,750, 1212-3.

4. Wilson TG, Kornman KS. Fundamentals of periodontics. Illinois: Quintessence Publishing Co. Inc.; 1996. p. 301,393.

5. Rose LF, Mealey BL. Periodontics: Medicine, surgery, and implants. Missouri: Mosby Inc. 2004. p. 26,43,46-8.

6. Simon H, Zieve D. Periodontal disease. [cited
2009 Des 7]. Available from: http://adam. about.com/reports/Periodontal-disease.htm 2009.

7. Lindhe J, Karing T, Lang NP. Clinical periodontology and implant dentistry. UK: Blackwell Munksgaard; 2003. p. 60, 216-20, 227, 233-5.

8. Setiawati EM. Efek sitoproteksi minosiklin pada epitel gingiva yang dipicu toksin bakteri Actinobacillus actinomycetemcomitans serotipe B. [cited 2009 Des 14]. Available from: http//www.adln.lib.unair.ac.id/print. php?id=gdlhub-gdl-s3-2009-setiawatie11096\&PHPSESSID=633b. 2009.

9. Houwink B. Ilmu kedokteran gigi pencegahan. Yogyakarta: Gajah Mada University Press; 1993. p. 12.

10. Survei Kesehatan Rumah Tangga. Jakarta: Departemen Kesehatan Republik Indonesia; 2001.

11. Situmorang, Nurmala. Dampak karies gigi dan penyakit periodontal terhadap kualitas hidup: Studi di dua kecamatan Kota Medan. Medan: USU Repository; 2004.

12. Rateitschak EM, Rateitschak KH, Wolf HF, Hassell TM. Color atlas of dental medicine periodontology. Stuttgart: Georg Thieme Verlag; 2004. p. 40-3, 50-1, 54-7, 60-2.

13. Sadeghi R. Prevalence of aggressive periodontitis in 15-18 years old schoolchildren in Tehran Iran. [cited 2009 Des 7]. Available from: http//www.cdhjournal.orgunpublished_view. php?article_id=108. 2003.

14. Albandar JM. Epidemiology of aggressive periodontitis in a South Brazilian population. [cited 2009 Des 7] Available from: http://iadr. confex.com/iadr/2005Balt/techprogram/ abstract_61689.htm 2005.

15. Fine, Daniel. Localized aggressive periodontitis: Pinning down the long suspected role of Actinobacillus actinomycetemcomitans. [cited 2009 Des 7]. Available from: http//www. nidcr.nih.gov/Research/ResearchResults/InterviewsOHR/Periodontitis.htm.2008.

16. Genco RJ, Goldman HM, Cohen DW. Contemporary periodontics. St. Louis, MI: Mosby Co.; 1990. p. 113,185 .

17. Samaranayake LP. Essential microbiology for dentistry. $2^{\text {nd }}$ ed. London: Churchill Livingstone; 2002. p. 113,122-123,230.

18. Löe H, Brown LJ. Early-onset periodontitis in 
the United States of America. J Periodontol $1991 ; 62: 608$.

19. Rosenberg JD. Gingivitis. 2010. [cited 2010 Jul 22]. Available from: http://www.nlm.nih. gov/medlineplus/ency/article/001056.htm.

20. Hormand J, Frandsen A. Juvenile periodontitis:
Localization of bone loss in relation to age, sex, and teeth. J Clin Periodontol 1979;6:407-16.

21. Burmeister JA, Best AM, Palcanis KG. Caine FA. Ranney RR. Localized juvenile periodontitis and generalized severe periodontitis: Clinical findings. J Clin Periodontol 1984;11:181-92. 